\title{
Controlling Citrus Huanglongbing: Green Sustainable Development Route Is the Future
}

OPEN ACCESS

Edited by:

Hong Luo,

Clemson University, United States

Reviewed by:

Subhas Hajeri,

Citrus Pest Detection Program, United States

Doron Teper,

Agricultural Research Organization (ARO), Israel

*Correspondence:

Xiangchun Meng

mengxiangchun@gdaas.cn

Wenli Chen

chenw/@scnu.edu.cn

${ }^{\dagger}$ These authors share first authorship

Specialty section:

This article was submitted to

Plant Biotechnology,

a section of the journal

Frontiers in Plant Science

Received: 18 August 2021 Accepted: 06 October 2021 Published: 15 November 2021

Citation:

Li X, Ruan H, Zhou C, Meng X and Chen W (2021) Controlling Citrus Huanglongbing: Green Sustainable

Development Route Is the Future.

Front. Plant Sci. 12:760481.

doi: 10.3389/fpls.2021.760481

\begin{abstract}
Xue $\mathrm{Li}^{1,2 t}$, Huaqin Ruan ${ }^{6 \dagger}$, Chengqian Zhou ${ }^{7}$, Xiangchun Meng ${ }^{3,4,5 *}$ and Wenli Chen ${ }^{1,2 *}$
'MOE Key Laboratory of Laser Life Science, Institute of Laser Life Science, Guangzhou, China, ${ }^{2}$ Guangdong Provincial Key Laboratory of Laser Life Science, College of Biophotonics, South China Normal University, Guangzhou, China, ${ }^{3}$ Key Laboratory of South Subtropical Fruit Biology and Genetic Resource Utilization (MOA), Guangzhou, China, ${ }^{4}$ Key Laboratory of Tropical and Subtropical Fruit Tree Research, Guangzhou, China, ${ }^{5}$ Institute of Fruit Tree Research, Guangdong Academy of Agricultural Science, Guangzhou, China, ${ }^{6}$ State Key Laboratory of Biocontrol and Guangdong Key Laboratory of Plant Resources, School of Life Sciences, Sun Yat-sen University, Guangzhou, China, ${ }^{7}$ Neuroscience Laboratory, Hugo Moser Research Institute at Kennedy Krieger, Baltimore, MD, United States
\end{abstract}

Huanglongbing (HLB) is the most severe bacterial disease of citrus crops caused by Candidatus Liberibacter spp. It causes a reduction in fruit yield, poor fruit quality, and even plants death. Due to the lack of effective medicine, HLB is also called citrus "AIDS." Currently, it is essential for the prevention and control of HLB to use antibiotics and pesticides while reducing the spread of HLB by cultivating pathogen-free seedlings, removing disease trees, and killing Asian citrus psyllid (ACP). New compounds [e.g., antimicrobial peptides (AMPs) and nanoemulsions] with higher effectiveness and less toxicity were also found and they have made significant achievements. However, further evaluation is required before these new antimicrobial agents can be used commercially. In this review, we mainly introduced the current strategies from the aspects of physical, chemical, and biological and discussed their environmental impacts. We also proposed a green and ecological strategy for controlling HLB basing on the existing methods and previous research results.

Keywords: citrus huanglongbing, sustainable development, physical method, antibiotic, antimicrobial peptide, genetically modified technology, nanotechnology, microbial therapy

\section{INTRODUCTION}

Huanglongbing (HLB), named for the leaf yellowing of diseased citrus, was first discovered in the Chaoshan area of Guangdong Province, China in the 1910s (Reinking, 1919). The typical symptoms of HLB-infected citrus are leaf yellowing, and roots rot in varying degrees (Bové and Barros, 2006). Even worse, HLB-affected fruits become smaller, taste sour, and bitter, and are prone to abscission (Bassanezi et al., 2009). HLB has caused a huge financial loss in the citrus industry. With the deepening of globalization, HLB has spread from Asia to Africa and the Americas (Faghihi et al., 2010; Lopes et al., 2010; Bassanezi et al., 2020). It has affected major citrus-producing areas and severely hindered the development of the citrus industry. Due to HLB, 7.4 million trees were lost in Guangxi, China alone in 2020, and more than 10 million diseased trees were destroyed all over China each year (Zhou, 2020). Many countries, namely China, the United States, and Brazil, have attached great importance to the prevention and control of HLB and invested heavily in related fields. How to defeat HLB has long been a common problem faced by all countries. 
It goes through the process of the nematode from fusarium to a virus to mycoplasma in the understanding of HLB pathogens. With the maturity of microscope technology, the peptidoglycan layer was observed under the electron microscope between the outer membrane and inner membrane of the HLB pathogen, which proved that it belongs to Gram-negative bacteria (Garnier et al., 1984). At present, it is commonly believed that the HLB pathogen belongs to Candidatus Liberibacter spp. of the $\alpha$-proteobacteria, mainly divided into Candidatus Liberibacter asiaticus (Ca.Las), Candidatus Liberibacter africanus (Ca.Laf), and Candidatus Liberibacter americanus (Ca.Lam) according to regionality, heat sensitivity, and 16S rDNA (Bové, 1974; Bové and Barros, 2006). Among them, Ca.Las is the most pathogenic and widely distributed species. HLB caused by Ca.Las has been reported in more than 20 countries and regions (Sechler et al., 2009; Hartung et al., 2010).

Candidatus Liberibacter asiaticus can infect almost all parts of the plant, but its distribution varies in different tissues (Johnson et al., 2014; Hajeri and Yokomi, 2019). The bacterial titer of leaves and stems is higher than in other parts of the plant. The Asian citrus psyllid (ACP) feeds on the phloem sap of citrus trees. Ca.Las enters into the body of ACP and multiplies in the insect gut by this way. Then, they spread from the gut to the salivary gland and gonad by blood circulation. Eventually, Ca.Las is transmitted to new hosts during ACP sucks sap from healthy plants (Grafton-Cardwell et al., 2013; Kruse et al., 2019). Bacteria deliver effector proteins into host cells through many kinds of secretion systems. Ca.Las only encodes genes for type I secretion system (T1SS) and Sec-dependent secretion system, whereas the genes of other secretion systems are lacking (Duan et al., 2009; Wang et al., 2017). The gene encoding a protein of the serralysin family was found next to the T1SS of Ca.Las. The previous study has shown that this protein played an important role in the bacteria against host defense. It also has strongly expressed in citrus phloem (Felfoldi et al., 2009; Faghihi et al., 2010; Cong et al., 2012). Thus, this protein may be a potential effector protein. Virulence factors of Ca.Las are secreted to the phloem elements or companion cells of citrus primarily by the Sec-dependent secretion system (Samiksha et al., 2016; Wang et al., 2017). The Sec-dependent secretory protein 1 (SDE1) has been identified in detail. It can suppress host defense response to promote bacterial invasion and colonization by interacting with citrus papain proteases (Marco et al., 2016). In addition, Zhang et al. (2020) found that the secretory protein CLIBASIA_04405 could inhibit the hypersensitivity and $\mathrm{H}_{2} \mathrm{O}_{2}$ accumulation in tobacco. The discovery of secretory proteins provides the basis for studying the pathogenicity mechanism of Ca.Las. Because most of Ca.Las cannot be purified and cultured in vitro, studies that the microbial-host molecular level has been greatly limited.

The struggle against HLB has been persisted for more than one century. Numerous scholars have made great contributions to the research of HLB during this period (Bassanezi et al., 2020). However, there is no cure. Some medicines have been widely used to ensure the healthy development of the citrus industry, such as antibiotics, pesticides, and immune inducers, which have achieved remarkable results (Zhang et al., 2011; Stockwell and Duffy, 2012). In 2018, the United States Department of Agriculture and Environmental Protection approved the combination of terramycin and streptomycin to control citrus HLB (Hijaz et al., 2021). Besides, cutting off the transmission route is also an essential step for controlling HLB (Zheng et al., 2018). Regrettably, these methods cannot completely get rid of the pathogen. With the increasing awareness of human environmental protection, the trend of biological control of HLB is becoming increasingly popular. The identification of new antimicrobial peptides (AMPs) and the application of transgenic technology have provided new hope for the control of HLB.

Fosthiazate (FOS) is a commercial organophosphorus pesticide that can effectively kill nematodes, and cupricammonium complex (CAC) is a broad-spectrum fungicide with low toxicity. Our laboratory found that the combined therapy of CAC and FOS was effective for HLB (Duan et al., 2021). Accumulated pieces of evidence show that a single measure is not strong enough to control HLB, and management of HLB requires integrating prevention with control. In this article, we summarize and discuss the HLB control methods, such as physical methods, chemical methods, and biological methods (Figure 1), hope to provide a reference for the comprehensive administration of HLB. In addition, we also propose an environmentally friendly strategy for controlling HLB (Figure 2).

\section{PHYSICAL METHODS}

\section{Heat Therapy}

Heat therapy has long been used in the field of plant disease management because high temperatures can cause cell lysis and thus kill bacteria (Schuster et al., 1973). In apple trees, the rubberwood virus can be eliminated by heat therapy (Campbell, 1961). In the 1960s, heat therapy has been utilized to treat citrus HLB by Kongxiang Lin (Lin and Luo, 1965). Nowadays, this approach has already been shown productive and widely used in the study of HLB. Among the three pathogenic bacteria, Ca.Las is able to tolerate temperatures above $35^{\circ} \mathrm{C}$ (Bové, 1974). Therefore, a temperature above $40^{\circ} \mathrm{C}$ is usually selected as a heat treatment condition in the greenhouse. We compared the results from different investigators and found that the symptoms of HLBinfected trees were alleviated to a certain extent after continuous treatment between 40 and $50^{\circ} \mathrm{C}$. The Ca.Las titer decreased to undetectable levels and most of the trees restored health in treated groups compared with untreated groups (Hoffman et al., 2013; Fan et al., 2016; Munir et al., 2018). All these experimental results show that heat therapy is effective against HLB. Although it has been proposed that heat stress may damage the citrus plants, many studies show that it can enhance plant metabolism and thus increase plant growth vigor and productivity (Lin and Luo, 1965). However, the presence of germs in citrus roots results in difficulty treating in wild. Limited by human and material resources, heat therapy is currently difficult to be applied in orchards.

\section{Interrupting the Pathway of Transmission}

The two major transmission pathways of HLB are grafting diseased branches and spreading by ACP. Therefore, interrupting the pathway of transmission can effectively reduce the spread of 


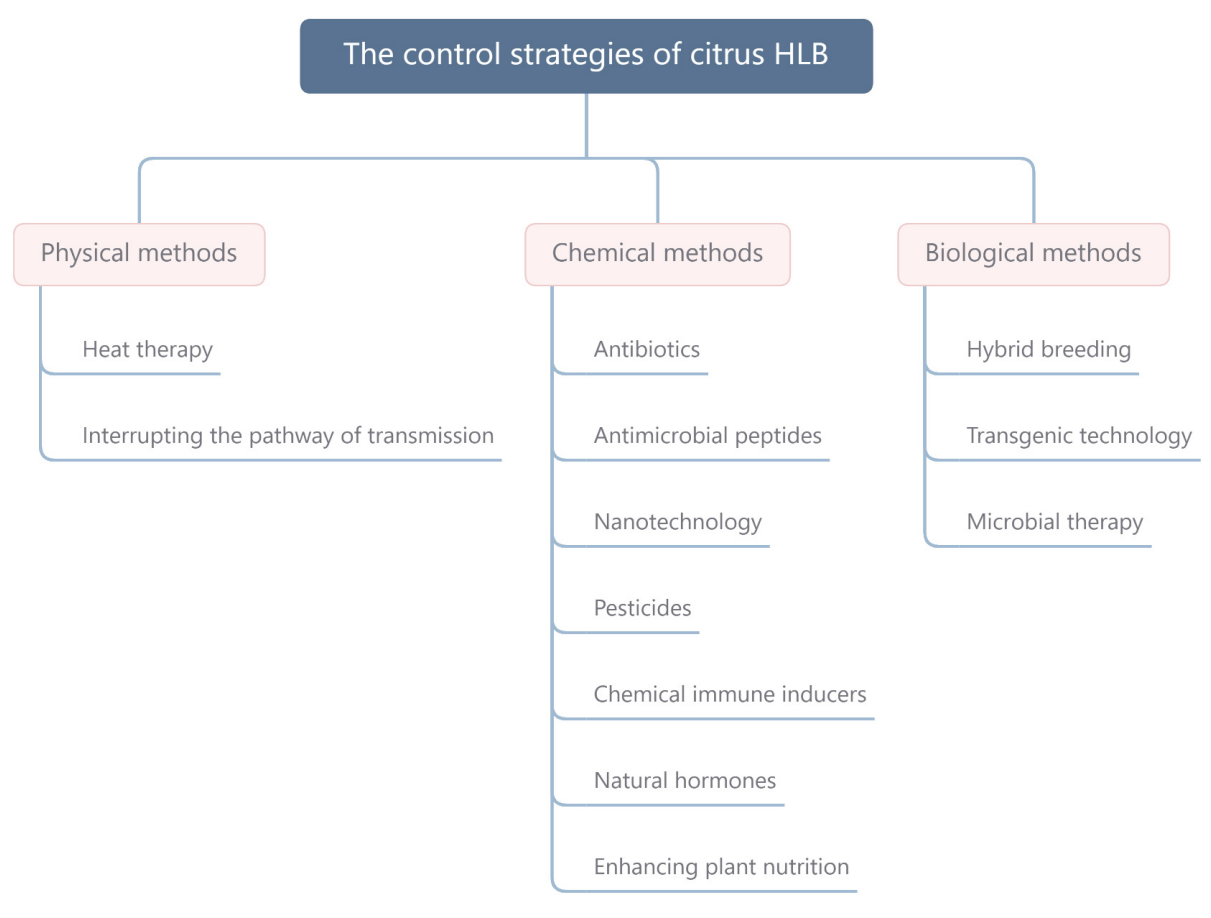

FIGURE 1| The control strategies of citrus HLB mainly include physical methods, chemical methods, and biological methods. HLB, huanglongbing.

HLB. The "three-step method" has been proved to be effective in reducing the spread of HLB (Lin, 1963), which is still adopted by countries all over the world.

\section{The Cultivation of Pathogen-Free Seedlings and Uprooting Diseased Trees}

Using the seedlings which are acquired from diseased trees or polluted breeding bases is responsible for the crazy spread of HLB in citrus. So, building a citrus pathogen-free breeding system is important for containing the transmission of HLB (Navarro, 1992). Presently, there are mainly three kinds of acquiring pathogen-free seedlings: (1) heat treatment: the pathogen can be fully cleared in quality buds by treating for consecutive $8 \mathrm{~h}$ and total for at least $40 \mathrm{~h}$ at $40-50^{\circ} \mathrm{C}$ (Hoffman et al., 2013; Fan et al., 2016). (2) Stem tips culture: plant apex tissues containing little or no germs and viruses are the ideal material to obtain pathogen-free seedlings (Prasad et al., 2012; Juárez et al., 2015). This technology has become one of the main techniques to culture pathogen-free seedlings. (3) Micrografting: micrografting technology is a method that combines stem tips culture and grafting, and culturing pathogen-free seedlings are mainly achieved by grafting pathogen-free stem tips onto a sterile plate (Starrantino and Caruso, 1988; Abbas et al., 2008). It is worth noting that every detoxification technology is inseparable from heat treatment. The pathogen-free seedlings must be identified (phenotypic identification or qPCR detection) before the promotion and application (Arredondo Valdés et al., 2016). Because all parts of diseased citrus may carry the pathogen, it is ineffective to control HLB only by cutting diseased branches (Lopes et al., 2007). Therefore, suspected diseased trees should be detected as soon as once they were found in the orchard. Once confirmed, it needs to uproot the HLB-infected trees, and the stumps should be perfused with herbicide and covered with film to prevent regeneration. In theory, the primary location should not be re-implanted for a number of years. In addition, strengthening orchard management can effectively reduce the burst rate of HLB (Bové and Barros, 2006). The orchards with poor management are more likely to relapse HLB than a wellmanaged orchard.

\section{Controlling Asian Citrus Psyllid}

Asian citrus psyllid is another major transmission medium of HLB, so controlling ACP is essential for preventing HLB (Grafton-Cardwell et al., 2013; Bassanezi et al., 2020; Li et al., 2020). ACP is easily attracted to yellow objects and methyl salicylate. Yielding lots of methyl salicylate and leaf yellowing further attract ACP to suck the sap of diseased trees results in the spread of HLB (Tiwari et al., 2010). Thus, it is necessary to eliminate ACP in time to prevent the spread of HLB after finding diseased trees (Grafton-Cardwell et al., 2013). Currently, the most frequent method of reducing ACP is through the use of chemical drugs, such as pyriproxyfen (Boina et al., 2010), imidacloprid (Katsuya et al., 2010), horticultural mineral oil (Teck et al., 2012), and aldicarb (Qureshi and Stansly, 2010). It was found that the cytochrome P450 monooxygenases (CYP4) genes were associated with insecticides resistance in ACP. The CYP4 expression of Ca.Las-infected ACP was lower than noninfected ACP, this showed that infected ACP was more sensitive to insecticides (Tiwari et al., 2011a,b). However, chemical drugs are unfriendly to the environment, other beneficial insects, and 


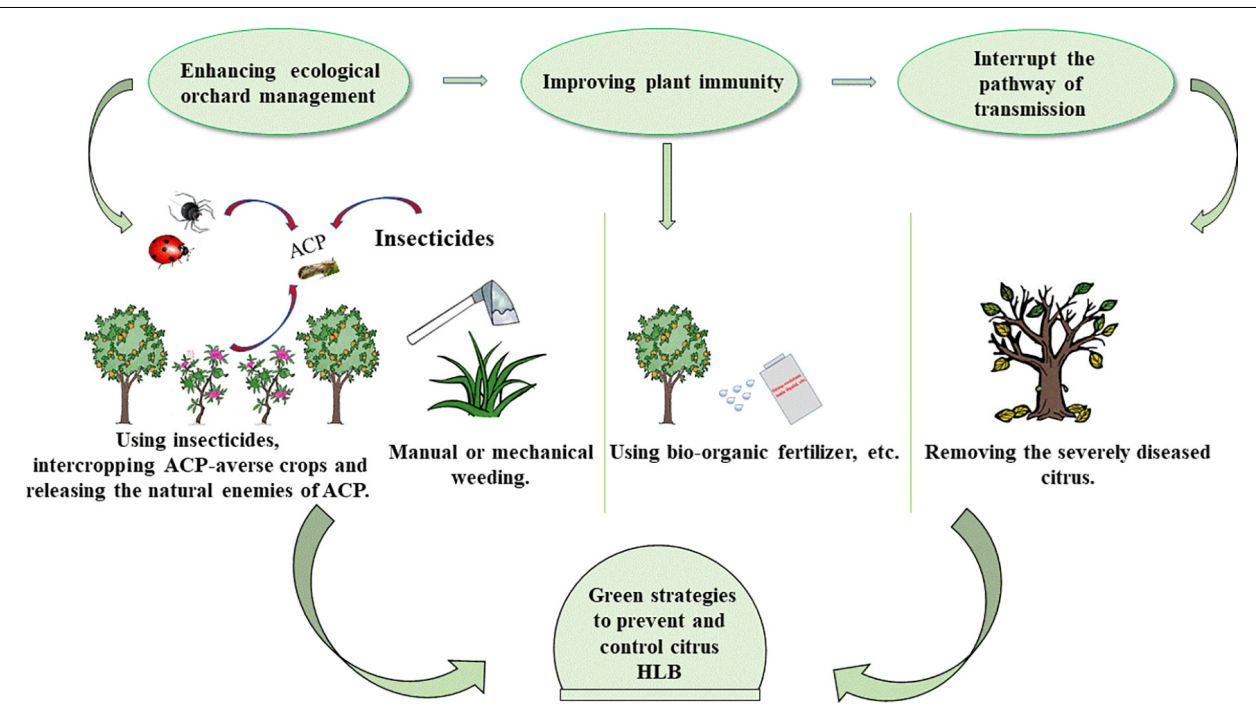

FIGURE 2 | Green strategies to prevent and control HLB. There are mainly three steps: first of all, enhancing the management of orchards by manual or mechanical weeding, intercropping ACP-averse crops, and releasing the natural enemies of ACP. Secondly, improving plant immunity. Using bio-organic fertilizer, spraying metabolic photosynthetic accelerators, and stress-resistant ionic liquids to enhance plant immunity. Finally, removing the severely diseased citrus to cutoff HLB from the source. HLB, Huanglongbing; ACP, Asian citrus psyllid.

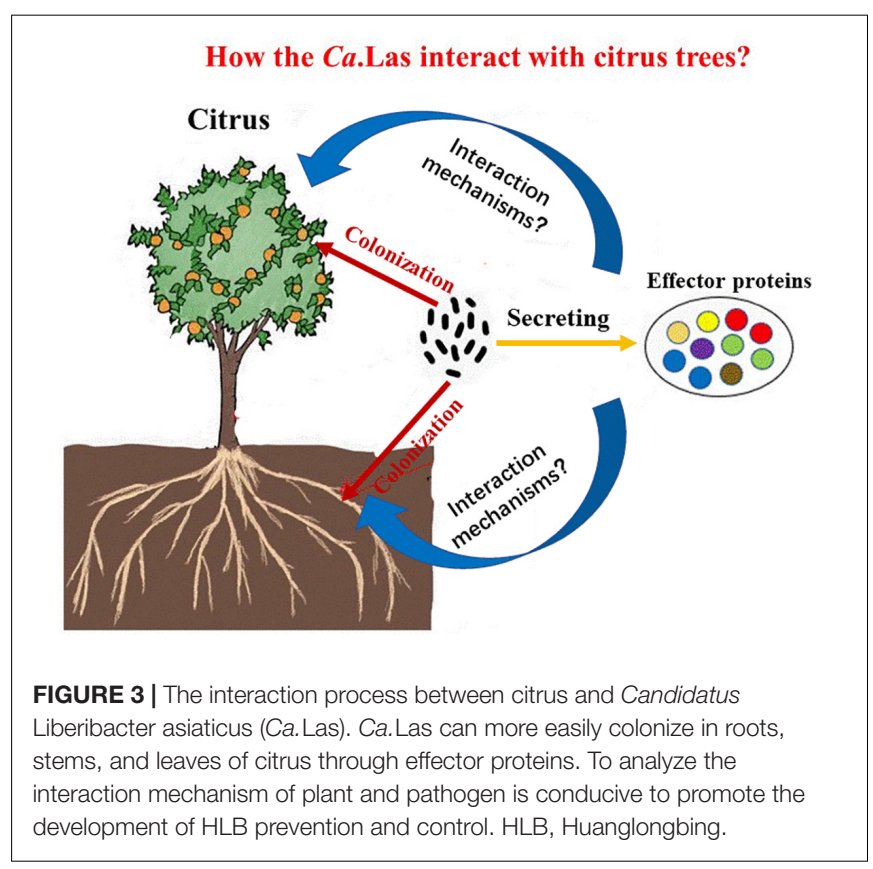

human health. Due to the short life cycle and strong reproductive capacity of ACP, the drugs are regularly applied every year. The resistance of ACP may be enhanced under intensive application of insecticides and thus lead to the weakening effect of the drugs (Liu and Tsai, 2000; Wenninger and Hall, 2007). Hence, compared with chemical drugs, biological control of ACP has greater development prospects, mainly including (1) entomopathogenic fungal therapy: Isaria fumosorosea (Meyer et al., 2008; Hoy et al., 2010; Hunter et al., 2011), Hirsutella citriformis (Meyer et al., 2007; Casique-Valdes et al., 2011), and other fungi are known to be able to infect ACP and also powerful candidates for biocontrol. (2) Parasite therapy: Tamarixia radiata and Psyllaephagus are two important ACP parasitic insects (Waterston, 1922; Hoy, 2001) that can be used to control ACP populations. (3) Insect viruses therapy: insect viruses are also candidates for biocontrol of ACP. For example, Diaphorina citri-associated C virus, Diaphorina citri picorna-like virus, and Diaphorina citri flavi-like virus are expected to be potential vectors for delivering RNA interference (RNAi) directly to ACP instead of Citrus tristeza virus (CTV) vector system (Britt et al., 2020). (4) Natural enemy predation therapy: ladybugs, spiders, and syrphid flies are natural enemies of ACP (Qureshi and Stansly, 2009; Shivankar and Rao, 2010). To some extent, releasing these natural enemies is also in favor of limiting ACP population growth. Subsequently, it was found that guava leaves and their volatiles (Onagbola et al., 2011), lavender essential oil, rose essential oil, tea tree essential oil, rutin essential oil, and other natural organic compounds exerted a repellent effect on ACP (Tiwari et al., 2010). Therefore, intercropping citrus with ACP-averse crops is also a method to reduce HLB transmission. Of course, biological control of ACP is not a highly effective control method. It is not highly reliable, and it can be influenced by so many other factors. Organic growers might use it but conventional growers cannot rely solely on biological control. Using insecticides is the cost-effective and most efficient strategy for controlling ACP (Li et al., 2020). To reduce the frequency of use of insecticides and mitigate the resistance of ACP, we propose adopting comprehensive management strategies that include releasing ACP natural enemies, intercropping ACP-averse crops, and using insecticides after attracting and aggregating ACP by the yellow sticky board or transgenic citrus.

Depending on interrupting the pathway of transmission can only stop the spread of HLB instead of curing it. 


\section{CHEMICAL METHODS}

\section{Antibiotics}

Since antibiotics were discovered, they have made a significant contribution to the control of bacterial diseases in plants (Stockwell and Duffy, 2012). Tetracycline has been widely used to treat HLB in various countries as early as the 1970s ( $\mathrm{Su}$ and Chang, 1974). However, it was later replaced by other antibiotics, such as penicillin, streptomycin, and terramycin, according to the poor results of assessment for tetracycline (Zhang et al., 2012, 2014; Hu et al., 2018). In fact, co-treatment with two antibiotics worked better than that of either antibiotic alone. Zhang et al. (2011) found that the regeneration rate of plants after stems of HLB-infected trees was immersed in penicillin (100 $\mu \mathrm{g} / \mathrm{ml})$-streptomycin $(10 \mu \mathrm{g} / \mathrm{ml})$ for $4 \mathrm{~h}$ was higher than other treatments. Today, hygromycin and streptomycin have been allowed to be used commercially (Hijaz et al., 2021). To investigate the transport process of antibiotics in citrus, fluorescence-labeled penicillin was injected into citrus and observed with fluorescence microscopy (Carl Zeiss Microscopy $\mathrm{GmbH}$, Göttingen, Germany). The fluorescence was detected in tissues of the plant and ACP (Killiny et al., 2019). The hygromycin also was observed in xylem- and phloem-related tissues after $24 \mathrm{~h}$ when trunk injection. It was detected in leaves after 3 days, and only very little was detected in roots (Hijaz et al., 2020, 2021). These results suggest that antibiotics are transported to various organs following the "vascular system" of the plant, and the transport efficiency varies depending on the tissues. The influence of antibiotics on the plants' growth and fruit quality is the major concern problem. It was shown that the application of penicillin and hygromycin increased N, P, K, S, and Zn contents in leaves, soluble organic matter content in fruits, and the nutritional status of citrus trees (Zhang M. et al., 2021). Although antibiotics brought convenience to agricultural production, their usage was controversial. The first point was the costs and the damage to plants of antibiotics (Zhang et al., 2014; Li et al., 2020). On the other hand, antibiotics may also increase bacterial resistance and cause superbugs (Bryson and Demerec, 1955). In addition, trunk injection leads to a better effect of antibiotics than traditional spraying. But it is very difficult in actual practice due to the large costs of human and material resources. The development of an efficient and convenient trunk injection method will play a key role in the treatment of HLB.

\section{Antibacterial Peptides}

Antimicrobial peptides are small-molecule proteins with extensive antimicrobial activity secreted by the host and have a regulatory effect on immune response (Koczulla and Bals, 2003). Ca.Las mainly infects Citrus and its related genera of Rutaceae, but different varieties have different sensitivity to HLB (Folimonova et al., 2009). When infected, severe symptoms of leaves yellowing and easily fall off occurred in most commercial citrus whereas Citrus medica (C. medica) and Poncirus trifoliata ( $P$. trifoliata) with tolerance to HLB had mild or no symptoms and normal growth and development (Albrecht and Bowman, 2011, 2012). Huang et al. (2021) have identified a short antimicrobial peptide (SAMP) that was only present in HLB-tolerant citrus by analysis of small RNA and mRNA between HLB-susceptible and HLB-tolerant citrus cultivars. Compared with antibiotics, the greatest advantages of SAMP were its thermal stability and high efficiency, which made it more suitable for practical application. Moreover, the SAMP was extremely easy to be degraded by pepsin and had higher safety (Wang et al., 2021). AMPs have been studied for a long time in citrus HLB control. Stover et al. (2013) used the Agrobacterium tumefaciens, Sinorhizobium meliloti, and Xanthomonas citri subsp. citri as experimental materials to explore the bactericidal effect of 44 broad-spectrum AMPs. It was also bactericidal property at lower concentrations (1 $\mu \mathrm{M})$. AMPs as safe and efficient antibacterial agents are suitable alternatives to antibiotics in agricultural production. However, the studies of AMPs are primarily focused on the level of basic research, and also the preparation cost of AMPs is too high for its commercial applications in controlling HLB.

\section{Nanotechnology}

Nanotechnology is an interdisciplinary technology with a wide range of applications. In the agricultural field, it is mainly used for disease management and control (Rai and Ingle, 2012) and includes (1) diagnosis of the crop diseases by using nanosensors (Gitaitis and Walcott, 2007). (2) Metal nanomaterials control crop diseases. (3) To improve drug utilization through nanoemulsion complexes. Spraying on the leaves is the major form of drugs administered in the field. However, the drug uptake efficiency of plants is greatly hindered due to the presence of the hydrophobic wax layer on the surface of citrus leaves. Due to the small size, nanoparticles can modify the property of drugs and enhance the absorption rate of plants for drugs. In recent years, nanotechnology has also been applied to treat citrus diseases and achieved good results. Young et al. (2018) applied $\mathrm{ZnO}-\mathrm{nCuSi}$ with the low phytotoxic composite to treat citrus. Field experiments showed that $\mathrm{ZnO}-\mathrm{nCuSi}$ had strong antibacterial activity to effectively control citrus canker. Kumar et al. (2018) found that nano$\mathrm{ZnO}-2 \mathrm{~S}$ albumin protein was able to significantly inhibit the growth of Ca.Las. Although some metal agents (such as $\mathrm{ZnO}$ ) have been considered as fertilizers for agricultural production, they do not play the biggest function due to their low solubility. This problem was not solved until the advent of nanoscale metal agents, which have high solubility and larger specific surface area, can catalyze the production of singlet oxygen and show strong bactericidal ability. Currently, nanoscale $\mathrm{ZnO}$ and silver nanoparticles (AgNPs) have been proved that not only have good bactericidal effects but effectively enhance plant resistance to fungal diseases, such as citrus scab and melanosis too (Graham et al., 2016; Stephano-Hornedo et al., 2020). Compared with the treatment of $\beta$-lactam antibiotics, the content of starch granules present in phloem sieve tubes and the Ca.Las titers were also significantly reduced after being treated by using AgNPs in HLBinfected trees (Stephano-Hornedo et al., 2020). Nanotechnology has brought new ideas for the prevention and treatment of HLB. Nanocomposites not only improve the utilization of drugs, they reduce the usage of drugs and also alleviate environmental 
pressure. Because we successfully silenced the NPR1 gene using AuNPs carrying siRNANPR1 (Lei et al., 2020). Our laboratory is developing a nano-genetic technology to activate a defense system for improving resistance by transferring resistant genes to hosts through nanomaterials, hoping to contribute to the prevention and treatment of HLB.

\section{Pesticides}

Citrus trees often suffer damage from nematodes (Cobb, 1914; Verdejo-Lucas and Mckenry, 2004). So far, more than 40 species of citrus parasitic nematodes have been identified worldwide, with two main common species: Meloidogyne and Pratylenchus spp. (Govaerts et al., 2007; Collange et al., 2011). The nematodes not only damage citrus roots and reduce new roots growth, but they can also affect roots development and the ability to absorb nutrients result in the decreased ability to resist diseases (Damadzadeh and Maafi, 2008). It was well known that sieve tube occlusion of HLB-infected citrus caused difficulty in transporting organic matter from leaves to the roots. The nematode colonization was a double blow to roots and thus making symptoms worse (Pourreza et al., 2016). Our study also found the presence of Tylenchulus semipenetrans juveniles in the roots of heavily diseased citrus (Duan et al., 2021). Therefore, controlling nematodes is also a necessary step in the treatment of HLB. Some herbicides are also commonly used in agricultural management, such as glyphosate (Duke and Powles, 2010), paraquat (Manning-Bog et al., 2002), atrazine (Hayes, 2002), and FOS (Duan et al., 2021). The use of pesticides provides conveniences in orchard management while safety concerns also cannot be ignored. For instance, the accumulation of pesticides can destroy the ecological balance and endanger human body health. Therefore, it is better to adopt hand or mechanical weeding and the way of soil fumigation and deep tillage to reduce nematodes during the process of HLB prevention and control (Eden and Stirlingl, 2008). In addition, the use of pesticides should be reduced, and organic fertilizers should be properly applied to restore the soil condition.

\section{Chemical Immune Inducers}

Systemic acquired resistance (SAR) is a crucial defense mechanism against pathogen invasion mediated by salicylic acid (SA) in plants (Mou et al., 2003). SA is one of the important signaling molecules in the SAR pathway. A large amount of methyl salicylate, which can be transformed into SA under the action of SA methyltransferase, is rapidly synthesized when Ca.Las invades citrus. The expression of pathogen-associated proteins $(P R s)$ induced by SA can improve the disease resistance of plants (Kumar and Klessig, 2008; Herrera-Vásquez et al., 2015). However, the genome annotation results showed that there were genes encoding SA hydroxylase in Ca.Las, Ca.Laf, and Ca.Lam (Duan et al., 2009; Lin et al., 2013; Katoh et al., 2014). It can degrade SA to hydroxyl SA which cannot induce the expression of $P R s$, and thus reduce the disease resistance of the plants (Li et al., 2017). Some exogenous chemical reagents have the function of activating plant immunity and can be used as a substitute for SA, such as imidacloprid, $\beta$-aminobutyric acid, 2,3-benzothiadiazole, and 2,6-dichloroisoniazid. These immune activators are more stable than SA and not easily degraded by SA hydroxylase secreted by bacteria. It has been shown that surface spraying or trunk injection immune inducers could induce PRs expression and enhance plant resistance for a period of time (Francis et al., 2009; Graham and Myers, 2013; Li et al., 2016; Palmer et al., 2019). Field experiments showed that these immune inducers could also control the development of HLB and had a positive impact on citrus yield and fruit quality (Li et al., 2016).

\section{Natural Hormones}

Natural hormones are also important regulators for plant growth and development (Yokota, 1997). High brassinosteroid (HBR), a kind of brassinosteroids (BRs), is a natural hormone that is widely distributed in pollen, seeds, stems, and leaves of plants and plays an important regulatory role in plant growth metabolism (Grove et al., 1979; Bishop and Takao, 2001). BRs can not only help plants cope with various extreme environmental stresses (Divi et al., 2010; Xia et al., 2011) but also improve plant resistance to pathogens (Ali et al., 2013). HBR was used to treat 2-yearold diseased citrus in the greenhouse in Cuba, the results showed that the symptoms were significantly improved and the bacterial titer of diseased citrus even decreased to an undetectable level (Canales et al., 2016). Melatonin is also an important plant regulator of inhibition effect on Ca.Las (Nehela and Killiny, 2020). In addition, other natural hormones also play a key role in host response under biological or non-biological stress, such as SA, jasmonic acid (JA), and ethylene (ET) (Mur et al., 2006; Bari and Jones, 2009). Other plant metabolites may also have directly or indirectly influenced the immune regulation against HLB. However, the regulatory mechanisms of most metabolites are unknown and need further research. Although these immune activators improve the nutritional status of citrus, the effect of immune inducers is negatively correlated with the age and disease severity of citrus trees (Li et al., 2016). Therefore, immune activators can be used as adjuvants to prevent HLB.

\section{Enhancing Plant Nutrition}

The early symptoms caused by HLB are similar to those caused by the lack of trace elements (Mattos et al., 2020). Zn and P deficiencies could also promote HLB occurrence (Zhao et al., 2013). Sieve tube occlusion caused by Ca.Las can limit the transport and absorption of nutrients. Therefore, an additional nutrient supply can alleviate HLB symptoms and prolong plant life (Pustika et al., 2008). Studies have indicated that the $\mathrm{N}$, $\mathrm{Mn}, \mathrm{Zn}$, and SA contents were significantly higher in the leaf of nutrient supply trees than the no-nutrient supply trees (Shen et al., 2013). The microbiota has a regulatory effect on plant growth and development and that the microbial abundance could be changed by using Zn-containing additive (Zhang et al., 2016). This further demonstrated the important function of increasing additional nutrients in plant growth. Because the effect is related to the level of disease, additional nutrient supply is more effective when it is applied at the earlier phase of infection. Certainly, only enhancing nutrition does not effectively control HLB, or even bacterial titer can be increased in the short term (Gottwald et al., 2012). Therefore, it should be treated with the simultaneous use of nutrients (e.g., nitrogen fertilizer and mixed fertilizer) and 
defense activators for the early control of HLB (Li et al., 2019; Zhang et al., 2019).

Since there are no specific drugs that can cure HLB, the overuse of chemical drugs may cause a series of safety problems in the environment and biology. So biological method is the general trend of the prevention and treatment of HLB and also has made a great contribution to the control of other agricultural diseases.

\section{BIOLOGICAL METHODS}

\section{Hybrid Breeding}

New varieties with excellent traits were obtained by hybrid breeding (Ohgawara et al., 1994; Viloria and Grosser, 2005; Grosser et al., 2007, Grosser and Gmitter, 2011, and this technology has been often used to improve the stress resistance of citrus (Grosser, 2003). The resistance traits obtained through the somatic hybridization technique can be stably inherited to offspring. However, the leaf malformation was found in a new plant that fused the somatic cells of Citrus sinensis and Murraya exotica (Grosser and Olivares-Fuster, 2000). Reproductive isolation between citrus and its distant relatives results in these materials being unusable. Disease-resistant materials were obtained primarily through rootstock breeding in citrus, because of the long breeding cycle and complex operations of traditional breeding (Bowman and Joubert, 2020). P. trifoliata, C. medica, Citrus limon (C. limon), and other citrus germplasms that have HLB tolerance are the main rootstock source for citrus (Miles et al., 2017). Because rootstock affects the life, nutrition, and growth of citrus (Sabatino et al., 2019), different regions should choose suitable rootstock varieties. The plant traits of P. trifoliata and C. sunki are compatible so that their hybrids can obtain the characteristics of HLB tolerance and have mild disease symptoms when infected (Ramadugu et al., 2016; Curtolo et al., 2020). The application of hybrids with HLB tolerance is conducive to alleviating the pressure caused by HLB in the short term. These results not only indicate that there are defense mechanisms against $\mathrm{Ca}$.Las in HLB-tolerant plants but also tolerance characteristics can be inherited. Curtolo et al. (2020) revealed that the HLB tolerance mechanisms were related to the downregulation of gibberellin (GA) and the enhancement of the cell wall. The sensitivity of different plants to HLB may be related to the difference in phloem cell activity (Fan et al., 2012). These results are crucial for identifying key toleranceassociated genes, and candidate genes are expected to construct HLB-tolerant citrus through genetic engineering technology.

\section{Transgenic Technology}

Transgenic technology was widely used to improve varieties in agriculture and animal husbandry (Mitchell and Sheehy, 2000). The progress of cultivating new plants is slow through traditional hybrid breeding technology because of the long breeding cycle of citrus. Transgenic technology can not only shorten the production cycle but also break the incompatibility barrier of distant hybridization, and also keep the genotypic and phenotypic integrity of transgenic citrus. Recently, Endo et al. (2020) developed a fast-track breeding system to transfer the
CTV resistance of trifoliate orange into citrus germplasm, which greatly shortened the breeding cycle and was in favor of the application of transgenic technology.

The non-expresser of pathogenesis related protein 1 (NPR1), as a SA receptor, plays an important role in the SAR pathway (Mou et al., 2003; Spoel, 2003). Overexpression of AtNPR1 (the NPR1 of Arabidopsis thaliana) enhanced the disease resistance in transgenic crops, such as rice, apple (Chern et al., 2005; Malnoy et al., 2007; Sajad et al., 2017), and sweet orange (Zhang et al., 2010; Boscariol-Camargo et al., 2016). It was later found that transgenic citrus plants overexpressing AtNPR1 exhibited tolerance to HLB (Dutt et al., 2015). Transgenic plants had lower $\mathrm{Ca}$.Las titer and better growth state than non-transgenic plants under HLB stress (Dutt et al., 2015; Caserta et al., 2020). Citrus thionein is a known antibacterial agent, and transgenic citrus overexpressing thionein performed better under HLB stress compared to the non-transgenic citrus (Hao et al., 2016). The AMP genes previously mentioned are strong candidates for the construction of transgenic plants. For instance, transgenic plants overexpressing D4E1 obtained HLB tolerance because synthetic peptide D4E1 could lead to bacterial cell membrane lysis (Attílio et al., 2013; Caserta et al., 2020). However, transgenic plants can only increase tolerance to HLB, but cannot solve the problem fundamentally.

Transgenic technology is also applied to control ACP. Bacillus thuringiensis $(B t)$ toxin can effectively kill lepidopteran insects (Naranjo, 2011). Transgenic Bt citrus greatly reduced the use of pesticides and suppressed pests' growth. Some volatile organic compounds, such as the volatile $\beta$-caryophyllene, could repel ACP by affecting the behavior of pests, and the transgenic citrus had a low attraction for ACP to reduce the spread of HLB (Alquézar et al., 2017). Thus, it is considered an environmentally friendly way of controlling pests, and there is no obvious phenotypic change in transgenic citrus. However, transgenic products are facing great controversy. Since exogenous genes are expressed in fruits, the impact on human health is unknown. Especially in the EU and Japan, people generally oppose the application of this technology. In the future, solving and balancing this problem is inevitable (Grosser et al., 2009).

Citrus tristeza virus is a ubiquitous virus in citrus that can enter the ACP body by consuming sap. RNAi technology based on CTV has also become a new method for controlling pests. This transient expression vector is very stable and therefore considered for citrus HLB control (Folimonov et al., 2007). At present, some progress has been made in the field. Key genes involved in metabolism and growth are silenced in ACP when CTV-RNAi is ingested. Reducing the expression of the abnormal wing disc $(A w d)$ gene could not only cause ACP malformation but also increase mortality of adults (Hajeri et al., 2014). Besides, the ACP can be killed by insecticides, whereas this may lead to resistance to drugs. Thus, when CYP4 was silenced, the resistance would be reduced and allow insecticides to act at high potency (Killiny et al., 2014). CTV-t phytoene desaturase-silenced (PDS) plants can attract and gather ACP when planted in orchards. It is convenient to use insecticides to kill ACP. Just CTV-tPDS trees may appear photo-bleaching phenotype (Killiny et al., 2021). The application of a CTV-based vector system is much mature 
and simpler to apply than insect-virus-based vector technology. Citrus nurseries can start the seedling already inoculated with a CTV-based vector hence the whole new orchard is pre-treated with CTV-based biological control. In addition, a CTV-based vector can be applied to the existing trees in the field without the need to replant the whole orchard. It can be done by graft inoculating the existing trees with plant material carrying a CTV-based vector. On the other hand, insect-virus-based vectors are still under research, and researchers have no idea how to introduce the insect virus safely in the environment. How these ACP-insect viruses going to impact the other beneficial insects is untested territory.

\section{Microbial Therapy}

Soil is a natural large microbial storage, and plant roots are the major sites of microbial interaction (Zhang $K$. et al., 2021). Improving soil biodiversity is beneficial to strengthen the interaction between soil function and biological elements (Artursson et al., 2006). The benign cycle of root microbial flora is conducive to both improving the growth environment of citrus roots and the prevention and control of HLB (Trivedi et al., 2010). Compared to HLB-infected trees, there are lots of beneficial bacteria, such as Burkholderia spp. and S. meliloti, in the rhizosphere soil of healthy citrus. These beneficial bacteria can both compete with harmful bacteria and regulate the metabolic activities of citrus roots by inducing the secretion of secondary metabolites (Zhang et al., 2017). There are some seemingly healthy trees in diseased citrus orchards, which are called HLB "escape trees." Beneficial bacteria with antibacterial ability were also isolated from these citrus roots (Riera et al., 2017). These results further demonstrate that beneficial bacteria are essential for plant growth and health. A study showed that Burkholderia spp. that colonize host roots could increase the expression levels of SA pathway-related genes to improve the antiviral ability of plants (Zhang et al., 2017). According to the characteristics, microbial agents that contain actinobacteria, yeast, rhizobium, other beneficial bacteria, and plant growth regulators have been developed and applied to control HLB. The harm of microbial agents is much smaller than chemical fertilizers, which can avoid soil hardness and fusarium root rot caused by excessive use of drugs and fertilizers.

\section{CONCLUSION AND PERSPECTIVE}

Nowadays, to protect the environment, countries all over the world are paying more and more attention to sustainable agricultural development. Therefore, a combination of the above, we propose a more environmentally sustainable route for the control of HLB (Figure 2). First of all, it is imperative to enhance orchard management by green and integrated approach

\section{REFERENCES}

Abbas, M., Khan, M. M., Fatima, B., Iftikhar, Y., and Abbas, H. (2008). Elimination of Citrus tristeza closterovirus (CTV) and production of certified citrus plants through shoot-tip micrografting. Pakistan J. Bot. 40, 1301-1312. doi: 10.1094/ MPMI-21-6-0843 that includes hand or mechanical weeding, suppressing ACP in combination with chemical and biological methods, such as the use of insecticides and the release of pests natural enemies. In addition, corresponding treatment measures should be taken when other major citrus diseases are present. Secondly, strategies, such as using bio-organic fertilizer and spraying immune activators that improve the plants' growth environment and enhance plant immunity, have a great promise for controlling HLB. Finally, removal of severely diseased citrus is key to reducing transmission because the effect of medications is guided by the disease severity of HLB-infected citrus. We hope these strategies are useful for HLB.

Since the 21st century, rapid growth in science technologies has also promoted the development of HLB-related research. Transgenic technology and nanotechnology as green strategies have become a hotspot attracting many researchers worldwide. However, lacking HLB resistance genes is the biggest challenge for the application of transgenic technology. But global citrus resources are very abundant and most of them have not been systematically evaluated. It cannot be concluded that resistance genes are absent altogether. In fact, controlling HLB is still a challenging task for investigators and planters who have to face.

In our opinion, future research should focus on two key points, such as (1) the interaction mechanisms of plant-pathogen (Figure 3). Studying the physiological and biochemical changes of diseased trees is important to clarify the pathogenesis of HLB and search for efficient treatment strategies. It is also favorable for the targeted transport of nanoparticles in the host and facilitates the applications of nanotechnology. (2) Screening HLB-tolerant plants and resistance genes. This is a critical step in resistance breeding. Driven by the government policies, the development of HLB has largely been inhibited by current prevention and control strategies, and we believe that this problem will be overcome in the future.

\section{AUTHOR CONTRIBUTIONS}

$\mathrm{XL}$ and HR: conceptualization and compilation of data and designing of figures. $\mathrm{XL}, \mathrm{HR}$, and WC: writing part and proofreading. XL, XM, and CZ: language polishing. All authors contributed to the article and approved the submitted version.

\section{FUNDING}

This research was supported by the National Natural Science Foundation of China (Grant No. 31570256), a grant from the Science and Technology project of Guangzhou (Grant No. 201805010002), and Guangdong's Modern Industrial Technology System (Grant Nos. 2019KJ113 and 2019KJ116). 
Ali, S. S., Kumar, G., Khan, M., and Doohan, F. M. (2013). Brassinosteroid Enhances Resistance to Fusarium Diseases of Barley. Phytopathology 103, 12601267. doi: 10.1094/PHYTO-05-13-0111-R

Alquézar, B., Volpe, H. X. L., Magnani, R. F., de Miranda, M. P., Santos, M. A., Wulff, N. A., et al. (2017). $\beta$-caryophyllene emitted from a transgenic Arabidopsis or chemical dispenser repels Diaphorina citri, vector of Candidatus Liberibacters. Scient. Rep. 7, 5639-5639. doi: 10.1038/s41598-017-06119-w

Arredondo Valdés, R., Delgado Ortiz, J. C., Beltrán Beache, M., Anguiano Cabello, J., Cerna Chávez, E., Rodríguez Pagaza, Y., et al. (2016). A review of techniques for detecting Huanglongbing (greening) in citrus. Canad. J. Microbiol. 62, 803-811. doi: 10.1139/cjm-2016-0022

Artursson, V., Finlay, R. D., and Jansson, J. K. (2006). Interactions between arbuscular mycorrhizal fungi and bacteria and their potential for stimulating plant growth. Environ. Microbiol. 8, 1-10. doi: 10.1111/j.1462-2920.2005.00942. $\mathrm{x}$

Attílio, L. B., Mourão, F. A. A., Harakava, R., Silva, T. L. D., Miyata, L. Y., Stipp, L. C. L., et al. (2013). Genetic transformation of sweet oranges with the D4E1 gene driven by the AtPP2 promoter. Pesquisa Agropecuária Brasil. 48, 741-747. doi: 10.1590/S0100-204X2013000700006

Bari, R., and Jones, J. D. (2009). Role of plant hormones in plant defence responses. Plant Mole. Biol. 69, 473-488. doi: 10.1007/s11103-008-9435-0

Bassanezi, R. B., Lopes, S. A., de Miranda, M. P., Wulff, N. A., Volpe, H. X. L., and Ayres, A. J. (2020). Overview of citrus huanglongbing spread and management strategies in Brazil. Tropical Plant Pathol. 45, 251-264. doi: 10.1007/s40858020-00343-y

Bassanezi, R. B., Montesino, L. H., and Stuchi, E. S. (2009). Effects of huanglongbing on fruit quality of sweet orange cultivars in Brazil. Eur. J. Plant Pathol. 125, 565-572. doi: 10.1007/s10658-009-9506-3

Bishop, G. J., and Takao, Y. (2001). Plants Steroid Hormones, Brassinosteroids: Current Highlights of Molecular Aspects on their Synthesis/Metabolism, Transport, Perception and Response. Plant Cell Physiol. 42, 114-120. doi: 10. 1093/pcp/pce018

Boina, D. R., Rogers, M. E., Wang, N., and Stelinski, L. L. (2010). Effect of pyriproxyfen, a juvenile hormone mimic, on egg hatch, nymph development, adult emergence and reproduction of the Asian citrus psyllid, Diaphorina citri Kuwayama. Pest Manag. Sci. 66, 349-357. doi: 10.1002/ps.1880

Boscariol-Camargo, R. L., Takita, M. A., and Machado, M. A. (2016). Bacterial resistance in AtNPR1 transgenic sweet orange is mediated by priming and involves EDS1 and PR2. Trop. Plant Pathol. 41, 1-9. doi: 10.1007/s40858-0160108-2

Bové, J., and Barros, A. P. D. (2006). Huanglongbing: A destructive, newly emerging, century-old disease of citrus. J. Plant Pathol. 88, 7-37. doi: 10.4454/ jpp.v88i1.828

Bové, J. M. (1974). Influence of temperature on symptoms of California stubborn, South Africa greening, India citrus decline and Philippines leaf mottling diseases. Proc. conf. int. organ. Citrus Virol. 6, 12-15.

Bowman, K. D., and Joubert, J. (2020). Chapter 6 - Citrus rootstocks the Genus Citrus. Sawston: Woodhead Publishing, 105-127. doi: 10.1016/B978-0-12812163-4.00006-1

Britt, K., Gebben, S., Levy, A., Rwahnih, M. A., and Batuman, O. (2020). The Detection and Surveillance of Asian Citrus Psyllid (Diaphorina citri) Associated Viruses in Florida Citrus Groves. Front. Plant Sci. 10:1687. doi: 10.3389/fpls.2019.01687

Bryson, V., and Demerec, M. (1955). Bacterial resistance. Am. J. Med. 18, 723-737. doi: 10.1016/0002-9343(55)90187-X

Campbell, A. I. (1961). The Effect of Rubbery Wood Virus on the Stoolbed Production of Two Clonal Apple Rootstocks. J. Pomol. Horticult. 36, 268-273. doi: 10.1080/00221589.1961.11514021

Canales, E., Coll, Y., Hernández, I., Portieles, R., García, M. R., López, Y., et al. (2016). 'Candidatus Liberibacter asiaticus', Causal Agent of Citrus Huanglongbing, Is Reduced by Treatment with Brassinosteroids. PLoS One 11:e0146223. doi: 10.1371/journal.pone. 0146223

Caserta, R., Teixeira-Silva, N. S., Granato, L. M., Dorta, S. O., Rodrigues, C. M., Mitre, L. K., et al. (2020). Citrus biotechnology: What has been done to improve disease resistance in such an important crop? Biotechnol. Res. Innovat. 3, 95-109. doi: 10.1016/j.biori.2019.12.004

Casique-Valdes, R., Reyes-Martinez, A. Y., Sanchez-Pea, S. R., and Lopez-Arroyo, M. J. B. I. (2011). Pathogenicity of Hirsutella Citriformis (Ascomycota: Cordycipitaceae) to Diaphorina citri (Hemiptera: Psyllidae) and Bactericera
Cockerelli (Hemiptera: Triozidae). Florid. Entomol. 94, 703-705. doi: 10.1653/ 024.094.0341

Chern, M., Fitzgerald, H. A., Canlas, P. E., Navarre, D. A., and Ronald, P. C. (2005). Overexpression of a rice NPR1 homolog leads to constitutive activation of defense response and hypersensitivity to light. Mol. Plant Microbe Interact 18, 511-520. doi: 10.1094/MPMI-18-0511

Cobb, N. A. (1914). Citrus root nematode. J. Agricult. Res. 2, 217-230. doi: 10.1111/ j.1744-7348.1914.tb05414.x

Collange, B., Navarrete, M., Peyre, G., Mateille, T., and Tchamitchian. (2011). Rootknot nematode (Meloidogyne) management in vegetable crop production: The challenge of an agronomic system analysis. Crop. Protect. Guildford 30, 1251-1262. doi: 10.1016/j.cropro.2011.04.016

Cong, Q., Kinch, L. N., Kim, B. H., and Grishin, N. V. (2012). Predictive Sequence Analysis of the Candidatus Liberibacter asiaticus Proteome. PLoS One 7:e41071. doi: 10.1371/journal.pone.0041071

Curtolo, M., de Souza, Pacheco, I., Boava, L. P., Takita, M. A., Granato, L. M., et al. (2020). Wide-ranging transcriptomic analysis of Poncirus trifoliata, Citrus sunki, Citrus sinensis and contrasting hybrids reveals HLB tolerance mechanisms. Scient. Rep. 10, 1-14. doi: 10.1038/s41598-020-77840-2

Damadzadeh, M., and Maafi, Z. T. (2008). Incidence and control of the citrus nematode, Tylenchulus semipenetrans Cobb, in the north of Iran. Nematology 10, 113-122. doi: 10.1163/156854108783360096

Divi, U. K., Rahman, T., and Krishna, P. (2010). Brassinosteroid-mediated stress tolerance in Arabidopsis shows interactions with abscisic acid, ethylene and salicylic acid pathways. BMC Plant Biol. 10:151. doi: 10.1186/1471-2229-10151

Duan, J. W., Li, X., Zhang, J. Z., Cheng, B. P., Li, H. M., Liu, S. H., et al. (2021). Cocktail Therapy of Fosthiazate and Cupric-Ammoniun Complex for Citrus Huanglongbing. Front. Plant Sci. 12:479. doi: 10.3389/fpls.2021.643971

Duan, Y., Zhou, L., Hall, D. G., Li, W., and Gottwald, T. (2009). Complete genome sequence of citrus huanglongbing bacterium, 'Candidatus Liberibacter asiaticus' obtained through metagenomics. Mol. Plant Microbe Interact 22, 1011-1020. doi: 10.1094/MPMI-22-8-1011

Duke, S. O., and Powles, S. B. (2010). Glyphosate: a once-in-a-century herbicide. Pest Manag. Sci. 64, 319-325. doi: 10.1002/ps.1518

Dutt, M., Barthe, G., Irey, M., and Grosser, J. (2015). Transgenic Citrus Expressing an Arabidopsis NPR1 Gene Exhibit Enhanced Resistance against Huanglongbing (HLB; Citrus Greening). PLoS One 10:e0147657. doi: 10.1371/ journal.pone.0137134

Eden, G. R., and Stirlingl, M. (2008). The impact of organic amendments, mulching and tillage on plant nutrition, Pythium root rot, root-knot nematode and other pests and diseases of capsicum in a subtropical environment, and implications for the development of more sustainable vegetable farmin. Austral. Plant Pathol. 37, 123-131. doi: 10.1071/AP07090

Endo, T., Fujii, H., Omura, M., and Shimada, T. (2020). Fast-track breeding system to introduce CTV resistance of trifoliate orange into citrus germplasm, by integrating early flowering transgenic plants with marker-assisted selection. BMC Plant Biol. 20:224. doi: 10.1186/s12870-020-02399-z

Faghihi, M. M., Salehi, M., Bagheri, A., and Izadpanah, K. (2010). First report of citrus huanglongbing disease on orange in Iran. Plant Pathol. 58, 793-793. doi: 10.1111/j.1365-3059.2009.02051.x

Fan, G. C., Xia, Y. L., Lin, X. J., Hu, H. Q., Wang, X. D., Ruan, C. Q., et al. (2016). Evaluation of thermotherapy against Huanglongbing (citrus greening) in the greenhouse. J. Integr. Agricult. 15, 111-119. doi: 10.1016/S2095-3119(15)610851

Fan, J., Chen, C., Yu, Q., Khalaf, A., Achor, D. S., Brlansky, R. H., et al. (2012). Comparative transcriptional and anatomical analyses of tolerant rough lemon and susceptible sweet orange in response to 'Candidatus Liberibacter asiaticus' infection. Mole. Plant Microbe Interact. 25, 1396-1407. doi: 10.1094/MPMI-0612-0150-R

Felfoldi, G., Marokhazi, J., Kepiro, M., and Venekei, I. (2009). Identification of Natural Target Proteins Indicates Functions of a Serralysin-Type Metalloprotease, PrtA, in Anti-Immune Mechanisms. Appl. Environ. Microbiol. 75, 3120-3126. doi: 10.1128/AEM.02271-08

Folimonov, A. S., Folimonova, S. Y., Bar-Joseph, M., and Dawson, W. O. (2007). A stable RNA virus-based vector for citrus trees. Virology 368, 205-216. doi: 10.1016/j.virol.2007.06.038

Folimonova, S. Y., Robertson, C. J., Garnsey, S. M., Gowda, S., and Dawson, W. O. (2009). Examination of the responses of different genotypes of citrus to 
huanglongbing (citrus greening) under different conditions. Phytopathology 99, 1346-1354. doi: 10.1094/PHYTO-99-12-1346

Francis, M. I., Redondo, A., Burns, J. K., and Graham, J. H. (2009). Soil application of imidacloprid and related SAR-inducing compounds produces effective and persistent control of citrus canker. Eur. J. Plant Pathol. 124, 283-292. doi: 10.1007/s10658-008-9415-x

Garnier, M., Danel, N., and Bové, J. (1984). The Greening Organism is a Gram Negative Bacterium. Int. Organizat. Citrus Virol. Conf. Proc. 9, 115-124. doi: 10.5070/C59277J4JM

Gitaitis, R., and Walcott, R. (2007). The epidemiology and management of seedborne bacterial diseases. Annu. Rev. Phytopathol. 45, 371-397. doi: 10.1146/ annurev.phyto.45.062806.094321

Gottwald, T., Graham, J., Irey, M., McCollum, T., and Wood, B. W. (2012). Inconsequential effect of nutritional treatments on huanglongbing control, fruit quality, bacterial titer and disease progress. Crop Protection 36, 73-82. doi: 10.1016/j.cropro.2012.01.004

Govaerts, B., Fuentes, M., Mezzalama, M., Nicol, J. M., Deckers, J., Etchevers, J. D., et al. (2007). Infiltration, soil moisture, root rot and nematode populations after 12 years of different tillage, residue and crop rotation managements. Soil Tillage Res. 94, 209-219. doi: 10.1016/j.still.2006.07.013

Grafton-Cardwell, E. E., Stelinski, L. L., and Stansly, P. A. (2013). Biology and Management of Asian Citrus Psyllid, Vector of the Huanglongbing Pathogens. Annu. Rev. Entomol. 58, 413-432. doi: 10.1146/annurev-ento-120811-153542

Graham, J. H., Johnson, E. G., Myers, M. E., Young, M., Rajasekaran, P., Das, S., et al. (2016). Potential of Nano-Formulated Zinc Oxide for Control of Citrus Canker on Grapefruit Trees. Plant Dis. 100, 2442-2447. doi: 10.1094/PDIS-0516-0598-RE

Graham and J. H., and Myers, M. E., (2013). Integration of soil applied neonicotinoid insecticides and acibenzolar-S-methyl for systemic acquired resistance (SAR) control of citrus canker on young citrus trees. Crop Prot. 54, 239-243. doi: 10.1016/j.cropro.2013.09.002

Grosser, J. W. (2003). Somatic hybridization in citrus - a relevant technique for variety improvement in the 21st century. Plant Biotechnol. Beyond 110, 537-540. doi: 10.1007/978-94-017-2679-5-110

Grosser, J. W., Ananthakrishnan, G., Calovic, M., Serrano, P., Chandler, J. L., Gmitter, F. G., et al. (2007). Applications of somatic hybridization and cybridization in scion and rootstock improvement, with focus on citrus. Acta Horticult. 738, 73-81. doi: 10.17660/ActaHortic.2007.738.5

Grosser, J. W., Dutt, M., Omar, A., Orbovic, V., and Barthe, G. (2009). Progress towards the development of transgenic disease resistance in citrus. Int. Symp. Citrus Biotechnol. 892, 101-107. doi: 10.17660/ActaHortic.2011.892.12

Grosser, J. W., and Olivares-Fuster, P. O. (2000). Somatic hybridization in citrus: An effective tool to facilitate variety improvement. Vitro Cell. Devel. Biol. Plant 36, 434-449. doi: 10.1007/s11627-000-0080-9

Grove, M., Spencer, G. F., Rohwedder, W. K., Mandava, N., and Cook, J. (1979). Brassinolide, a plant growth-promoting steroid isolated from Brassica napus pollen. Nature 281, 216-217. doi: 10.1038/281216a0

Grosser, J. W., and Gmitter, F. G. (2011). Protoplast fusion for production of tetraploids and triploids: applications for scion and rootstock breeding in citrus. Plant Cell, Tissue Organ Cult. 104, 343-357. doi: 10.1007/s11240-010-9823-4

Hajeri, S., Killiny, N., El-Mohtar, C., Dawson, W. O., and Gowda, S. (2014). Citrus tristeza virus-based RNAi in citrus plants induces gene silencing in Diaphorina citri, a phloem-sap sucking insect vector of citrus greening disease (Huanglongbing). J. Biotechnol. 176, 42-49. doi: 10.1016/j.jbiotec.2014. 02.010

Hajeri, S., and Yokomi, R. K. (2019). Reliable Sampling tissue and seasonality for consistent detection of 'Candidatus Liberibacter asiaticus' by qPCR. Curr. Agri. Res. 8, 1-3. doi: 10.12944/CARJ.8.1.01

Hao, G., Stover, E., and Gupta, G. (2016). Overexpression of a Modified Plant Thionin Enhances Disease Resistance to Citrus Canker and Huanglongbing (HLB). Front. Plant Sci. 7:1078. doi: 10.3389/fpls.2016.01078

Hartung, J. S., Paul, C., Achor, D., and Brlansky, R. H. (2010). Colonization of dodder, Cuscuta indecora, by 'Candidatus Liberibacter asiaticus' and ' $\mathrm{Ca}$. $\mathrm{L}$. americanus'. Phytopathology 100, 756-762. doi: 10.1094/PHYTO-100-8-0756

Hayes, T. B. (2002). Hermaphroditic, demasculinized frogs after exposure to the herbicide atrazine at low ecologically relevant doses. Proc. Natl. Acad. Sci. U.S.A. 99, 5476-5480. doi: 10.1073/pnas.082121499

Herrera-Vásquez, A., Carvallo, L., Blanco, F., Tobar, M., Villarroel-Candia, E., Vicente-Carbajosa, J., et al. (2015). Transcriptional Control of Glutaredoxin GRXC9 Expression by a Salicylic Acid-Dependent and NPR1-Independent
Pathway in Arabidopsis. Plant Mole. Biol. Rep. 33, 624-637. doi: 10.1007/ s11105-014-0782-5

Hijaz, F., Nehela, Y., Al-Rimawi, F., Vincent, C. I., and Killiny, N. (2020). The Role of the Xylem in Oxytetracycline Translocation within Citrus Trees. Antibiotics 9, 691-701. doi: 10.3390/antibiotics9100691

Hijaz, F., Nehela, Y., Gonzalez-Blanco, P., and Killiny, N. (2021). Development of Europium-Sensitized Fluorescence-Based Method for Sensitive Detection of Oxytetracycline in Citrus Tissues. Antibiotics 10, 224-237. doi: 10.3390/ antibiotics 10020224

Hoffman, M. T., Doud, M. S., Williams, L., Zhang, M., and Duan, Y. P. (2013). Heat treatment eliminates 'Candidatus Liberibacter asiaticus' from infected citrus trees under controlled conditions. Phytopathology 103, 15-22. doi: 10.1094/ PHYTO-06-12-0138-R

Hoy, M. A., Singh, R., and Rogers, M. E. (2010). Evaluations of a Novel Isolate of Isaria fumosorosea for Control of the Asian Citrus Psyllid, Diaphorina citri (Hemiptera: Psyllidae). Florid. Entomol. 93, 24-32. doi: 10.1653/024.093.0103

Hoy, M. F. A. (2001). Survival of Diaphorina citri (Homoptera: Psyllidae), and Its Two Parasitoids, Tamarixia radiata (Hymenoptera: Eulophidae) and Diaphorencyrtus aligarhensis (Hymenoptera: Encyrtidae), under Different Relative Humidities and Temperature Regimes. Florid. Entomol. 84, 227-233. doi: $10.2307 / 3496171$

Hu, J., Jiang, J., and Wang, N. (2018). Control of Citrus Huanglongbing via Trunk Injection of Plant Defense Activators and Antibiotics. Phytopathology 108, 186-195. doi: 10.1094/PHYTO-05-17-0175-R

Huang, C. Y., Araujo, K., Sánchez, J., Kund, G., and Jin, H. (2021). A stable antimicrobial peptide with dual functions of treating and preventing citrus Huanglongbing. Proc. Natl. Acad. Sci. U.S.A. 118:e2019628118. doi: 10.1073/ pnas.2019628118

Hunter, W. B., Avery, P. B., Pick, D., and Powell, C. A. (2011). Broad Spectrum Potential of Isaria fumosorosea Against Insect Pests of Citrus. Florid. Entomol. 94, 1051-1054. doi: 10.1653/024.094.0444

Johnson, E. G., Wu, J., Bright, D. B., and Graham, J. H. (2014). Association of "Candidatus Liberibacter asiaticu" root infection, but not phloem plugging with root loss on huanglongbing-affected trees prior to appearance of foliar symptoms. Plant Pathol. 63, 290-298. doi: 10.1111/ppa.12109

Juárez, J., Aleza, P., and Navarro, L. (2015). Applications of citrus shoot-tip grafting in vitro. Acta Horticult. 1065, 635-642. doi: 10.17660/ActaHortic.2015.1065.79

Katoh, H., Miyata, S. I., Inoue, H., and Iwanami, T. (2014). Unique Features of a Japanese 'Candidatus Liberibacter asiaticus' Strain Revealed by Whole Genome Sequencing. PLoS One 9:e106109. doi: 10.1371/journal.pone.0106109

Katsuya, I., Bang, D. V., Tuan, D. H., and Dien, L. Q. (2010). Effective Use of Neonicotinoids for Protection of Citrus Seedlings From Invasion by Diaphorina citri (Hemiptera: Psyllidae). J. Econ. Entomol. 103, 127-135. doi: 10.1603/ EC09218

Killiny, N., Gonzalez-Blanco, P., Santos-Ortega, Y., Al-Rimawi, F., and Batuman, O. (2019). Tracing Penicillin Movement in Citrus Plants Using FluorescenceLabeled Penicillin. Antibiotics 8, 262-271. doi: 10.3390/antibiotics8040262

Killiny, N., Hajeri, S., Tiwari, S., Gowda, S., and Stelinski, L. L. (2014). Doublestranded RNA uptake through topical application, mediates silencing of five CYP4 genes and suppresses insecticide resistance in Diaphorina citri. PLoS One 9:e110536. doi: 10.1371/journal.pone.0110536

Killiny, N., Nehela, Y., George, J., Rashidi, M., Stelinski, L. L., and Lapointe, S. L. (2021). Phytoene desaturase-silenced citrus as a trap crop with multiple cues to attract Diaphorina citri, the vector of Huanglongbing. Plant Sci. 308:110930. doi: 10.1016/j.plantsci.2021.110930

Koczulla, A. R., and Bals, R. (2003). Antimicrobial Peptides. Drugs 63, 389-406. doi: 10.2165/00003495-200363040-00005

Kruse, A., Fleites, L. A., and Heck, M. (2019). Lessons from One Fastidious Bacterium to Another: What Can We Learn about Liberibacter Species from Xylella fastidiosa. Insects 10, 300-323. doi: 10.3390/insects 10090300

Kumar, D., Ghosh, Sunil, Kokane, Pranav, Kumar, et al. (2018). Antimicrobial nano-zinc oxide-2S albumin protein formulation significantly inhibits growth of "Candidatus Liberibacter asiaticus" in planta. PLoS One 13:e0204702. doi: 10.1371/journal.pone.0204702

Kumar, D., and Klessig, D. F. (2008). The search for the salicylic acid receptor led to discovery of the SAR signal receptor. Plant Signal. Behav. 3, 691-692. doi: 10.4161/psb.3.9.5844

Lei, W. X., An, Z. S., Zhang, B. H., Wu, Q., and Chen, W. L. (2020). Construction of gold-siRNA NPR1 nanoparticles for effective and quick silencing of NPR1 in Arabidopsis thaliana. RSC Adv. 10, 19300-19308. doi: 10.1039/d0ra02156c 
Li, J., Li, L., Pang, Z., Kolbasov, V. G., Ehsani, R., Carter, E. W., et al. (2019). Developing citrus huanglongbing (HLB) management strategies based on the severity of symptoms in HLB-endemic citrus-producing regions. Phytopathology 109, 582-592. doi: 10.1094/PHYTO-08-18-0287-R

Li, J., Pang, Z., Trivedi, P., Zhou, X., and Wang, N. (2017). 'Candidatus Liberibacter asiaticus' Encodes a Functional Salicylic Acid (SA) Hydroxylase That Degrades SA to Suppress Plant Defenses. MPMI 30, 620-630. doi: 10.1094/MPMI-12-160257-R

Li, J., Trivedi, P., and Wang, N. (2016). Field Evaluation of Plant Defense Inducers for the Control of Citrus Huanglongbing. Phytopathology 106, 37-46. doi: 10. 1094/PHYTO-08-15-0196-R

Li, S., Wu, F., Duan, Y., Singerman, A., and Guan, Z. (2020). Citrus greening: Management strategies and their economic impact. HortScience 55, 604-612. doi: 10.21273/HORTSCI14696-19

Lin, H., Han, C. S., Liu, B., Lou, B., and Gupta, G. (2013). Complete Genome Sequence of a Chinese Strain of "Candidatus Liberibacter asiaticus". Genome Announc. 1, e184-e113. doi: 10.1128/genomeA.00184-13

Lin, K. X. (1963). Further studies on citrus yellow shoot. J. Plant Protect. 2, 243-251. doi: 10.13802/j.cnki.zwbhxb.1963.03.004

Lin, K. X., and Luo, X. H. (1965). A preliminary study on thermotherapy of yellow shoot disease of citrus. J. Plant Protect. 4, 169-175. doi: 10.13802/j.cnki.zwbhxb. 1965.02.008

Liu, Y. H., and Tsai, J. H. (2000). Effects of temperature on biology and life table parameters of the Asian citrus psyllid, Diaphorina citri Kuwayama (Homoptera: Psyllidae). Anna. Appl. Biol. 137, 201-206. doi: 10.1111/j.1744-7348.2000. tb00060.x

Lopes, S. A., Frare, G. F., Camargo, L., Wulff, N. A., Teixeira, D. C., Bassanezi, R. B., et al. (2010). Liberibacters associated with orange jasmine in Brazil: incidence in urban areas and relatedness to citrus Liberibacters. Plant Pathol. 59, 1044-1053. doi: 10.1111/j.1365-3059.2010.02349.x

Lopes, S. A., Frare, G. F., Yamamoto, P. T., Ayres, A. J., and Barbosa, J. C. (2007). Ineffectiveness of pruning to control citrus huanglongbing caused by Candidatus Liberibacter americanus. Eur. J. Plant Pathol. 119, 463-468. doi: 10.1007/s10658-007-9173-1

Malnoy, M., Jin, Q., Borejszawysocka, E. E., He, S. Y., and Aldwinckle, H. S. (2007). Overexpression of the apple MPNPR1 gene confers increased disease resistance in Malus x domestica. Mol. Plant Microbe Interact. 20, 1568-1580. doi: 10.1094/MPMI-20-12-1568

Manning-Bog, A. B., Mccormack, A. L., Li, J., Uversky, V. N., Fink, A. L., and Monte, D. (2002). The Herbicide Paraquat Causes Up-regulation and Aggregation of $\alpha$-Synuclein in mice- paraquat and $\alpha$-synuclein. J. Biol. Chem. 277, 1641-1644. doi: 10.1074/jbc.C100560200

Marco, P., Armstrong, C. M., Cano, L. M., and Duan, Y. (2016). Transient Expression of Candidatus Liberibacter Asiaticus Effector Induces Cell Death in Nicotiana benthamiana. Front. Plant Sci. 7:982. doi: 10.3389/fpls.2016.00982

Mattos-Jr, D., Kadyampakeni, D. M., da Silva, J. R., Vashisth, T., and Boaretto, R. M. (2020). Reciprocal effects of huanglongbing infection and nutritional status of citrus trees: a review. Trop. Plant Pathol. 45, 586-596. doi: 10.1007/s40858-02000389-y

Meyer, J. M., Hoy, M. A., and Boucias, D. G. (2007). Morphological and molecular characterization of a Hirsutella species infecting the Asian citrus psyllid, Diaphorina citri Kuwayama (Hemiptera: Psyllidae), in Florida. J. Inver. Pathol. 95, 101-109. doi: 10.1016/j.jip.2007.01.005

Meyer, J. M., Hoy, M. A., and Boucias, D. G. (2008). Isolation and characterization of an Isaria fumosorosea isolate infecting the Asian citrus psyllid in Florida. J. Inver. Pathol. 99, 96-102. doi: 10.1016/j.jip.2008.03.007

Miles, G. P., Stover, E., Ramadugu, C., Keremane, M. L., and Lee, R. F. (2017). Apparent tolerance to huanglongbing in citrus and citrus-related germplasm. HortScience 52, 31-39. doi: 10.21273/hortsci11374- 16

Mitchell, P. L., and Sheehy, J. E. (2000). Genetic modification and agriculture. Stud. Plant 7, 257-268. doi: 10.1016/S0928-3420(00)80020-8

Mou, Z., Fan, W., and Dong, X. (2003). Inducers of Plant Systemic Acquired Resistance Regulate NPR1 Function through Redox Changes. Cell 113, 935944. doi: 10.1016/S0092-8674(03)00429-X

Munir, S., He, P., Wu, Y., He, P., Khan, S., Huang, M., et al. (2018). Huanglongbing Control: Perhaps the End of the Beginning. Microb. Ecol. 76, 192-204. doi: 10.1007/s00248-017-1123-7

Mur, L. A., Kenton, P., Atzorn, R., Miersch, O., and Wasternack, C. (2006). The outcomes of concentration-specific interactions between salicylate and jasmonate signaling include synergy, antagonism, and oxidative stress leading to cell death. Plant physiol. 140, 249-262. doi: 10.2307/4282048

Naranjo, S. E. (2011). Impacts of Bt transgenic cotton on integrated pest management. J. Agricult. Food Chem. 59, 5842-5851. doi: 10.1021/jf102939c

Navarro, L. (1992). Citrus Shoot Tip Grafting in Vitro. High Tech Micropropagat 18, 327-338. doi: 10.1007/978-3-642-76422-6_17

Nehela, Y., and Killiny, N. (2020). Melatonin Is Involved in Citrus Response to the Pathogen Huanglongbing via Modulation of Phytohormonal Biosynthesis. Plant Physiol. 184, 2216-2239. doi: 10.1104/pp.20.00393

Ohgawara, T., Uchimiya, H., Ishii, S., and Kobayashi, S. (1994). Somatic Hybridization Between Citrus sinensis and Poncirus trifoliata. Spring. Berl. Heidelb. 27, 439-454. doi: 10.1007/978-3-642-57945-5_30

Onagbola, E. O., Rouseff, R. L., Smoot, J. M., and Stelinski, L. L. (2011). Guava leaf volatiles and dimethyl disulphide inhibit response of Diaphorina citri Kuwayama to host plant volatiles. J. Appl. Entomol. 135, 404-414. doi: 10.1111/ j.1439-0418.2010.01565.x

Palmer, I. A., Chen, H., Chen, J., Chang, M., and Fu, Z. Q. (2019). Novel Salicylic Acid Analogs Induce a Potent Defense Response in Arabidopsis. Int. J. Mole. Sci. 20:3356. doi: 10.3390/ijms20133356

Pourreza, A., Lee, W. S., Etxeberria, E., and Zhang, Y. (2016). Identification of Citrus Huanglongbing Disease at the Pre-Symptomatic Stage Using Polarized Imaging Technique. IFAC Papers OnLine 49, 110-115. doi: 10.1016/j.ifacol. 2016.10.021

Prasad, M. G., Raja, D. S., Sri, K., Naik, M. S., and Jaffar, S. K. (2012). In vitro plant regeneration using shoot tip culture in commercial cultivar of teak. Int. J. Pharm. Technol. 4, 4287-4290.

Pustika, A., Subandiyah, S., Holford, P., Beattie, G., Iwanami, T., and Masaoka, Y. (2008). Interactions between plant nutrition and symptom expression in mandarin trees infected with the disease huanglongbing. Austral. Plant Dis. Notes 3, 112-115.

Qureshi, J. A., and Stansly, P. A. (2009). Exclusion techniques reveal significant biotic mortality suffered by Asian citrus psyllid Diaphorina citri (Hemiptera: Psyllidae) populations in Florida citrus. Biol. Control 50, 129-136. doi: 10.1016/ j.biocontrol.2009.04.001

Qureshi, J. A., and Stansly, P. A. (2010). Rate, placement and timing of aldicarb applications to control Asian citrus psyllid Diaphorina citri Kuwayama (Hemiptera: Psyllidae), in oranges. Pest Manag. Sci. 64, 1159-1169. doi: 10.1002/ ps. 1612

Rai, M., and Ingle, A. (2012). Role of nanotechnology in agriculture with special reference to management of insect pests. Appl. Microbiol. Biotechnol. 94, 287293. doi: 10.1007/s00253-012-3969-4

Ramadugu, C., Keremane, M. L., Halbert, S. E., Duan, Y. P., Roose, M. L., Stover, E., et al. (2016). Long-term field evaluation reveals Huanglongbing resistance in Citrus relatives. Plant Dis. 100, 1858-1869. doi: 10.1094/PDIS-03-16-0271-RE

Reinking, O. A. (1919). Diseases of economic plants in southern China. Phillip. Agric. 8, 109-135.

Riera, N., Handique, U., Zhang, Y., Dewdney, M. M., and Wang, N. (2017). Characterization of antimicrobial-producing beneficial bacteria isolated from huanglongbing escape citrus trees. Front. Microbiol. 8:2415. doi: 10.3389/fmicb. 2017.02415

Sabatino, L., Iapichino, G., Rotino, G. L., Palazzolo, E., Mennella, G., and D’Anna, F. (2019). Solanum aethiopicum gr. gilo and its interspecific hybrid with S. melongena as alternative rootstocks for eggplant: Effects on vigor, yield, and fruit physicochemical properties of cultivar' Scarlatti'. Agronomy 9, 223-238. doi: 10.3390/agronomy9050223

Sajad, A., Mir, Z. A., Anshika, T., Hailay, M., Meena, R. P., Bhat, J. A., et al. (2017). Overexpression of NPR1 in Brassica juncea Confers Broad Spectrum Resistance to Fungal Pathogens. Front. Plant Sci. 8:1693. doi: 10.3389/fpls.2017.01693

Samiksha, P., Xu, J., Zhang, Y., and Wang, N. (2016). SEC-Translocon Dependent Extracytoplasmic Proteins of Candidatus Liberibacter asiaticus. Front. Microbiol. 7:1989. doi: 10.3389/fmicb.2016.01989

Schuster, H., Beyersmann, D., Mikolajczyk, M., and Schlicht, M. (1973). Prophage Induction by High Temperature in Thermosensitive dna Mutants Lysogenic for Bacteriophage Lambda. J. Virol. 11, 879-885. doi: 10.1128/JVI.11.6.879-885. 1973

Sechler, A., Schuenzel, E. L., Cooke, P., Donnua, S., and Schaad, N. W. (2009). Cultivation of 'Candidatus Liberibacter asiaticus', 'Ca. L. africanus', and 'Ca. L. americanus' associated with huanglongbing. Phytopathology 99, 480-486. doi: 10.1094/PHYTO-99-5-0480 
Shen, W., Cevallos-Cevallos, J. M., Da Rocha, U. N., Arevalo, H. A., Stansly, P. A., Roberts, P. D., et al. (2013). Relation between plant nutrition, hormones, insecticide applications, bacterial endophytes, and Candidatus Liberibacter Ct values in citrus trees infected with Huanglongbing. Eur. J. Plant Pathol. 137, 727-742. doi: 10.1007/s10658-013-0283-7

Shivankar, V. J., and Rao, C. N. (2010). Psyllids and their management. Pest Manag. Horticult. Ecosystems 16, 1-4.

Spoel, S. H. (2003). NPR1 Modulates Cross-Talk between Salicylate- and Jasmonate-Dependent Defense Pathways through a Novel Function in the Cytosol. Plant Cell 15, 760-770. doi: 10.1105/tpc.009159

Starrantino, A., and Caruso, A. (1988). The shoot-tip grafting technique applied in citriculture. Acta Horticult. 227, 101-103. doi: 10.17660/ActaHortic.1988.227. 13

Stephano-Hornedo, J. L., Torres-Gutiérrez, O., Toledano-Magaa, Y., GradillaMartínez, I., Pestryakov, A., Sánchez-González, A., et al. (2020). Argovit silver nanoparticles to fight Huanglongbing disease in Mexican limes (Citrus aurantifolia Swingle). RSC Adv. 10, 6146-6155. doi: 10.1039/c9ra09018e

Stockwell, V. O., and Duffy, B. (2012). Use of antibiotics in plant agriculture. Rev. Scient. Techni. 31:199. doi: 10.20506/rst.31.1.2104

Stover, E., Stange, R. R., Mccollum, T. G., Jaynes, J., and Mirkov, E. (2013). Screening Antimicrobial Peptides In Vitro for Use in Developing Transgenic Citrus Resistant to Huanglongbing and Citrus Canker. J. Am. Soc. Horticultural. 138, 142-148. doi: 10.21273/JASHS.138.2.142

Su, H. J., and Chang, S. C. (1974). Electron microscopical study on the heat and tetracycline response, and ultra-structure of the pathogen complex causing citrus likubin disease. Proc. Int. Congr. Electr. Micros. 2, 628-629.

Teck, L., Fatimah, A., Andrew, B., Heng, K., and King, W. S. (2012). Impacts of Horticultural Mineral Oils and Two Insecticide Practices on Population Fluctuation of Diaphorina citri and Spread of Huanglongbing in a Citrus Orchard in Sarawak. Scient. World J. 2012:651416. doi: 10.1100/2012/651416

Tiwari, S., Gondhalekar, A. D., Mann, R. S., Scharf, M. E., and Stelinski, L. L. (2011a). Characterization of five CYP4 genes from Asian citrus psyllid and their expression levels in Candidatus Liberibacter asiaticus-infected and uninfected psyllids. Insect Mole. Biol. 20, 733-744. doi: 10.1111/j.1365-2583.2011.01103.x

Tiwari, S., Pelz-Stelinski, K., and Stelinski, L. L. (2011b). Effect of Candidatus Liberibacter asiaticus infection on susceptibility of Asian citrus psyllid, Diaphorina citri, to selected insecticides. Pest Manag. Sci. 67, 94-99. doi: 10. 1002/ps.2038

Tiwari, S., Smoot, J. M., Rouseff, R. L., and Stelinski, L. (2010). Repellency and toxicity of plant-based essential oils and their constituents against Diaphorina citri Kuwayama (Hemiptera: Psyllidae). J. Appl. Entomol. 136, 87-96. doi: 10. 1111/j.1439-0418.2010.01592.x

Trivedi, P., Duan, Y., and Wang, N. (2010). Huanglongbing, a Systemic Disease, Restructures the Bacterial Community Associated with Citrus Roots ${ }^{\nabla}$. Appl. Environ. Microbiol. 76, 3427-3436. doi: 10.1128/AEM.02901-09

Verdejo-Lucas, S., and Mckenry, M. V. (2004). Management of the Citrus Nematode, Tylenchulus semipenetrans. J. Nematol. 36, 424-432.

Viloria, Z., and Grosser, J. W. (2005). Acid Citrus Fruit Improvement via Interploid Hybridization Using Allotetraploid Somatic Hybrid and Autotetraploid Breeding Parents. J. Am. Soc. Horticult. Sci. 130, 392-402. doi: 10.21273/JASHS. 130.3.392

Wang, N., Pierson, E. A., Setubal, J. C., Xu, J., Levy, J. G., Zhang, Y. Z., et al. (2017). The Candidatus Liberibacter-Host Interface: Insights into Pathogenesis Mechanisms and Disease Control. Annu. Rev. Phytopathol. 55, 451-482. doi: 10.1146/annurev-phyto-080516-035513

Wang, X., Chen, J., Liu, N., and Fu, Z. Q. (2021). Dual Functions of a Stable Peptide against Citrus Huanglongbing Disease. Trends Plant Sci. 26, 668-670. doi: 10.1016/j.tplants.2021.04.006

Waterston, J. (1922). On the Chalcidoid Parasites of Psyllids (Hemiptera Homoptera). Bull. Entomol. Res. 13, 41-58. doi: 10.1017/S0007485300045235

Wenninger, E. J., and Hall, D. G. (2007). Daily timing of mating and age at reproductive maturity in Diaphorina citri (Hemiptera: Psyllidae). Florid. Entomol. 90, 715-722. doi: 10.1653/0015-4040200790

Xia, X., Zhou, Y., Ju, D., Kai, S., Asami, T., Chen, Z., et al. (2011). Induction of systemic stress tolerance by brassinosteroid in Cucumis sativus. New Phytol. 191, 706-720. doi: 10.1111/j.1469-8137.2011.03745.x

Yokota, T. (1997). The structure, biosynthesis and function of brassinosteroids. Trend Plant 2, 137-143. doi: 10.1016/S1360-1385(97)01017-0
Young, M., Ozcan, A., Myers, M. E., Johnson, E. G., Graham, J. H., and Santra, S. (2018). Multimodal Generally Recognized as Safe ZnO/Nanocopper Composite: A Novel Antimicrobial Material for the Management of Citrus Phytopathogens. J. Agric. Food Chem. 66, 6604-6608. doi: 10.1021/acs.jafc. $7 \mathrm{~b} 02526$

Zhang, C., Du, P. X., Yan, H. L., Zhu, Z. C., Wang, X. F., and Li, W. M. (2020). A Sec-Dependent Secretory Protein of the Huanglongbing-Associated Pathogen Suppresses Hypersensitive Cell Death in Nicotiana benthamiana. Front. Microbiol. 11:594669. doi: 10.3389/fmicb.2020.594669

Zhang, M., Guo, Y., Powell, C. A., Doud, M. S., Yang, C., and Duan, Y. (2014). Effective Antibiotics against 'Candidatus Liberibacter asiaticus' in HLB-Affected Citrus Plants Identified via the Graft-Based Evaluation. PLoS One 9:e111032. doi: 10.1371/journal.pone.0111032

Zhang, M., Guo, Y., Powell, C. A., Doud, M. S., Yang, C., and Duan, Y. (2016). Zinc treatment increases the titre of 'Candidatus Liberibacter asiaticus' in huanglongbing-affected citrus plants while affecting the bacterial microbiomes. J. Appl. Microbiol. 120, 1616-1628. doi: 10.1111/jam.13102

Zhang, M., Karuppaiya, P., Zheng, D., Sun, X., Bai, J., Ferrarezi, R. S., et al. (2021). Field Evaluation of Chemotherapy on HLB-Affected Citrus Trees With Emphasis on Fruit Yield and Quality. Front. Plant Sci. 12:611287. doi: 10.3389/ fpls.2021.611287

Zhang, K., Maltais-Landry, G., and Liao, H. L. (2021). How soil biota regulate $\mathrm{C}$ cycling and soil $\mathrm{C}$ pools in diversified crop rotations. Soil Biol. Biochem. 156:108219. doi: 10.1016/j.soilbio.2021.108219

Zhang, M., Powell, C. A., Guo, Y., Dou, M. S., and Duan, Y. (2012). A GraftBased Chemotherapy Method for Screening Effective Molecules and Rescuing Huanglongbing-Affected Citrus Plants. Phytopathology 102, 567-574. doi: 10. 1094/PHYTO-09-11-0265

Zhang, M., Powell, C. A., Zhou, L., He, Z., and Duan, Y. (2011). Chemical compounds effective against the citrus Huanglongbing bacterium 'Candidatus Liberibacter asiaticus' in planta. Phytopathology 101, 1097-1103. doi: 10.1094/ PHYTO-09-10-0262

Zhang, M., Yang, C., Powell, C. A., Avery, P. B., Wang, J., Huang, Y., et al. (2019). Field evaluation of integrated management for mitigating citrus huanglongbing in Florida. Front. Plant Sci. 9:1890. doi: 10.3389/fpls.2018.01890

Zhang, X., Francis, M. I., Dawson, W. O., Graham, J. H., Orbović, V., Triplett, E. W., et al. (2010). Over-expression of the Arabidopsis NPR1 gene in citrus increases resistance to citrus canker. Eur. J. Plant Pathol. 128, 91-100. doi: 10.1007/s10658-010-9633-x

Zhang, Y., Xu, J., Riera, N., Jin, T., Li, J., and Wang, N. (2017). Huanglongbing impairs the rhizosphere-to-rhizoplane enrichment process of the citrus rootassociated microbiome. Microbiome 5:97. doi: 10.1186/s40168-017-0304-4

Zhao, H., Sun, R., Albrecht, U., Padmanabhan, C., Wang, A., Coffey, M. D., et al. (2013). Small RNA profiling reveals phosphorus deficiency as a contributing factor in symptom expression for citrus huanglongbing disease. Mole. Plant 6, 301-310. doi: $10.1093 / \mathrm{mp} / \mathrm{sst} 002$

Zheng, Z., Chen, J. C., and Deng, X. L. (2018). Historical perspectives management, and current research of citrus HLB in guangdong province of China, where the disease has been endemic for over a hundred years. Phytopathology 108, 1224-1236. doi: 10.1094/PHYTO-07-18-0255-IA

Zhou, C. (2020). The status of citrus Huanglongbing in China. Trop. Plant Pathol 45, 279-284. doi: 10.1007/s40858-020-00363-8

Conflict of Interest: The authors declare that the research was conducted in the absence of any commercial or financial relationships that could be construed as a potential conflict of interest.

Publisher's Note: All claims expressed in this article are solely those of the authors and do not necessarily represent those of their affiliated organizations, or those of the publisher, the editors and the reviewers. Any product that may be evaluated in this article, or claim that may be made by its manufacturer, is not guaranteed or endorsed by the publisher.

Copyright (C) $2021 \mathrm{Li}$, Ruan, Zhou, Meng and Chen. This is an open-access article distributed under the terms of the Creative Commons Attribution License (CC BY). The use, distribution or reproduction in other forums is permitted, provided the original author(s) and the copyright owner(s) are credited and that the original publication in this journal is cited, in accordance with accepted academic practice. No use, distribution or reproduction is permitted which does not comply with these terms. 